Dispersed Manufacturing Networks 
Rob Dekkers

Editor

\section{Dispersed Manufacturing Networks}

Challenges for Research and Practice 


\section{Editor}

Rob Dekkers, PhD

Div. Management \& Business Economics

Paisley Business School

PA1 2BE Paisley

UK

dek.rob@gmail.com

ISBN 978-1-84882-467-6

e-ISBN 978-1-84882-468-3

DOI 10.1007/978-1-978-1-84882-468-3

Springer Dordrecht Heidelberg London New York

British Library Cataloguing in Publication Data

A catalogue record for this book is available from the British Library

Library of Congress Control Number: 2009929379

(C) Springer-Verlag London Limited 2009

GPSS World ${ }^{\mathrm{TM}}$ is a registered trademark of Minuteman Software

Apart from any fair dealing for the purposes of research or private study, or criticism or review, as permitted under the Copyright, Designs and Patents Act 1988, this publication may only be reproduced, stored or transmitted, in any form or by any means, with the prior permission in writing of the publishers, or in the case of reprographic reproduction in accordance with the terms of licenses issued by the Copyright Licensing Agency. Enquiries concerning reproduction outside those terms should be sent to the publishers.

The use of registered names, trademarks, etc., in this publication does not imply, even in the absence of a specific statement, that such names are exempt from the relevant laws and regulations and therefore free for general use.

The publisher makes no representation, express or implied, with regard to the accuracy of the information contained in this book and cannot accept any legal responsibility or liability for any errors or omissions that may be made.

Cover design: eStudioCalamar, Figueres/Berlin

Printed on acid-free paper

Springer is part of Springer Science+Business Media (www.springer.com) 


\section{TO NIL AND MERT}




\section{Acknowledgements}

Many have contributed to this edited book, most of all the authors of the respective chapters. Without their research and their efforts and the intense correspondence that lead to the stage where we are now, this book on Dispersed Manufacturing Networks, would not have been possible. The authors always showed understanding by their quick and adequate responses to numerous requests. It was a privilege to work with the authors and exchange thoughts on this topic that is at the forefront of academic research.

Secondly, I would like to acknowledge my gratitude to David Bennett, editor of the Journal of Manufacturing Technology Management, and Emerald Group Publishing, the publisher of that journal, for their permission to build on the papers of the Special Issue on Dispersed Manufacturing Networks, which appeared in 2006 (Volume 17, Issue 8); this concerns Chapters 3, 6, 7, 8, 10 and 11. All these earlier journal papers have been amended to account for the progress made during the two years after the Special Issue. Two chapters that did not make it to Special Issue, mostly due to the pressing deadlines, complement the rewritten versions of the journal papers; these chapters (4 and 9, based on the earlier submissions) help to complete the picture of Dispersed Manufacturing Networks and provide additional insight. Furthermore, it should be noted that an earlier version of Chapter 2 appeared in the proceedings of the $12^{\text {th }}$ International EurOMA Conference, held in Budapest (2005); the discussions at that conference inspired the writing of this chapter as it is now. Moreover, an earlier version of Chapter 5 appeared in the proceedings of the $9^{\text {th }}$ Annual Cambridge International Manufacturing Symposium, Cambridge (2004), again encouraged by remarks of the participants.

Thirdly, my indebtedness extends to the reviewers, particularly for the efforts they made for appraising all possible contributions to the Special Issue of the Journal of Manufacturing Technology Management, which in turn formed the base for the writings in the book. All chapters, except Chapter 2 and 5, were initially reviewed by: Luis Camarinha-Matos, Vittorio Chiesa, Martin Christopher, David Bennett, Angappa Gunasekaran, Ian Hipkin, Bernard Hon, Thanos Kourouklis, Hermann Kühnle, Sameer Kumar, W.B. Lee, Bart MacCarthy, Mohamed Naim, Andrew Nee, Günther Schuh, Jongyiang Shi, Ann Vereecke, Jack van der Vorst, Seungjin Wang, and Zhang Shu. The critiques were constructive and extensive allowing the authors to reshape the chapters and to take in consideration the valuable comments in addition to my reviewing and remarks.

Fourthly, I credit Carole Gould, Shishank Shishank, Kumaran Sugumaran and Julie Thomson, who have all assisted with the final proofing of the manuscripts. Particularly, Kumaran Sugumaran and Shishank Shishank have taken the time to do the proofing for the majority of the chapters.

Finally, I would like to thank Springer UK (Anthony Doyle, Claire Protherough and Simon Reese) and their editor of the Advanced Manufacturing Series, Duc Truong Pham, for the opportunity to compile and publish this edited book. 
Should I have forgotten anyone who has contributed or provided valuable assistance, they should consider this an acknowledgement of their effort and an apology at the same time.

Rob Dekkers

Paisley, 31 December 2008 


\section{Contents}

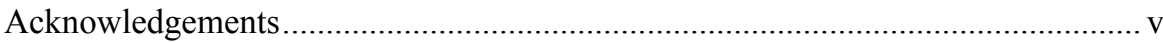

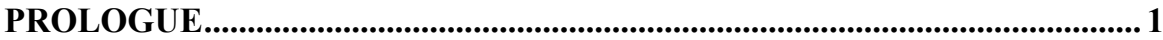

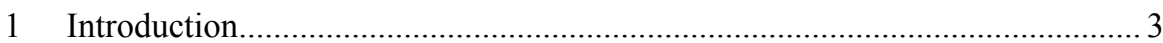

2 Industrial Networks of the Future: Review of Research and Practice............. 13 Rob Dekkers and David Bennett

PART I: Networks as Complex Adaptive Systems 35

3 Dispersed Network Manufacturing: An Emerging Form of Collaboration

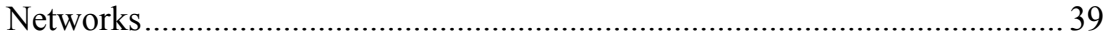

Hamid Noori and W.B. Lee

4 Self-Similarity and Criticality in Dispersed Manufacturing: A Contribution to Production Networks Control ...................................................................... 59

Hermann Kühnle

5 Collaborations in Industrial Networks: The Co-Evolutionary Perspective ..... 77 Rob Dekkers

PART II: Control and Coordination in Industrial Networks

6 Designing and Modeling Agile Supply-Demand Networks

Petri Helo, Natalia Kitaygorodskaya, Sari Salminen and Roger J. Jiao

7 Framework for Developing an Agile Future-Proof Supply Chain.

Hossein Sharifi, Hossam Ismail and Iain Reid

PART III: International Issues of Industrial Networks

8 Developing a Worldwide Production Network........................................... 159 Joachim Kuhn

9 Planning in Companies with Dispersed Capacity. Stephen A. Smith, David J. Petty, David G. Trustrum and Ashraf W. Labib

10 Managing Product Variety in Multinational Corporation Supply Chains: A Simulation Study Investigating Flow Time

Mahendrawathi Er and Bart MacCarthy

11 Set-Up and Operation of Global Engineering Networks Spanning Industrialized and Emerging Economies

Harshavardhan Karandikar 


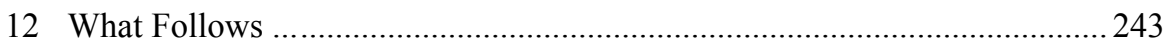

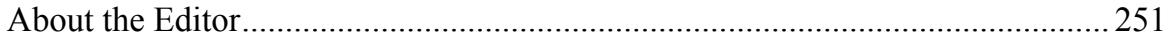

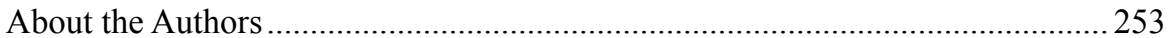

